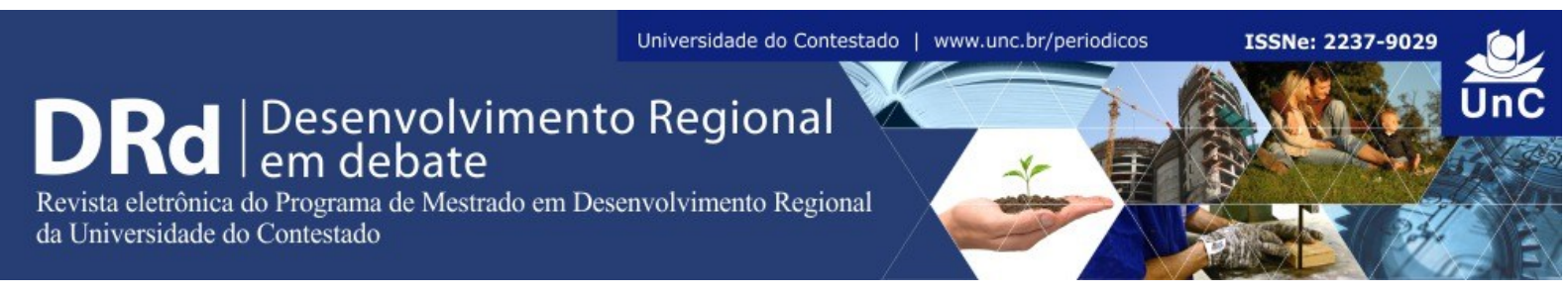

\title{
COM ERVA-MATE NÃO SE FAZ SÓ CHIMARRÃO! SITUAÇÃO ATUAL E PERSPECTIVAS DE INOVAÇÃO NO SETOR ERVATEIRO DO PLANALTO NORTE CATARINENSE
}

\author{
Valdir Roque Dallabridal \\ Caroline Ianoski Dumke ${ }^{2}$ \\ Simone Molz ${ }^{3}$ \\ Valéria Furini ${ }^{4}$ \\ Maria Bertilia Oss Giacomelli ${ }^{5}$
}

\begin{abstract}
RESUMO
Entre as diferentes acepções atribuídas à inovação, uma delas é sua compreensão como a capacidade empresarial de introduzir novos produtos no mercado. Partindo dessa compreensão, é possível conjeturar que a diversidade e quantidade de produtos com que um setor produtivo opera pode ser tomada como um indicador de inovação. Tomando o exemplo da erva-mate, a variedade de produtos que atualmente utilizam essa matéria-prima se aproxima a uma centena, o que representa avanços inovacionais, considerando que até pouco tempo seu uso se restringia à produção da erva-mate para chimarrão e chá. No Planalto Norte Catarinense, região que historicamente se destacou na produção de erva-mate, estão instaladas dezenas de empresas do setor, sendo que, em mais de $70 \%$ delas, a erva-mate para chimarrão é o único produto. Essa constatação motivou uma investigação no setor, com o fim de avaliar as condições efetivas de inovação, e seus desafios, considerando avanços sobre novos usos da erva-mate e novos produtos com que o mercado mundial opera atualmente. $O$ estudo compreendeu consulta em sites de empresas brasileiras e mundiais, com o intuito de reconhecer a variedade de produtos que utilizam a erva-mate como matéria-prima, além da realização de uma pesquisa de campo, numa amostra de empresas da região. O estudo evidenciou a prevalência de fitocosméticos a base de erva mate e a reduzida diversidade de produtos com que operam as empresas estudadas e seu baixo nível de inovação. Tal realidade aponta para a necessidade de avanços no setor ervateiro regional, exigindo ações não apenas do setor empresarial, mas das instituições de pesquisa e extensão instaladas na região.
\end{abstract}

Palavras-chave: Erva-Mate. Inovação. Desenvolvimento Territorial. Planalto Norte Catarinense.

\footnotetext{
${ }^{1}$ Geógrafo, doutor em Desenvolvimento Regional, com atuação no Programa de Mestrado em Desenvolvimento Regional (PMDR) da Universidade do Contestado (UnC). Santa Catarina. Brasil. E-mail: valdirdallabrida@gmail.com

2 Bolsista de Iniciação Científica no curso de Administração da UnC. Santa Catarina. Brasil. E-mail: carolinedumke_@hotmail.com

${ }^{3}$ Farmacêutica, com Mestrado e Doutorado em Neurociência pela UFSC, atuando no curso de Farmácia da UnC. Santa Catarina. Brasil. E-mail: simonem@unc.br

${ }^{4}$ Farmacêutica e mestranda em Desenvolvimento Regional da UnC, com atuação no curso de Farmácia da UNOESC. Santa Catarina. Brasil. E-mail: farmaciavaleria@hotmail.com

${ }^{5}$ Graduação e Doutorado em Química, com atuação no Instituto Federal de Educação, Ciência e Tecnologia de Santa Catarina (IFSC)-Campus Canoinhas. Santa Catarina. Brasil. E-mail: bertilia@ifsc.edu.br.
} 


\section{ABSTRACT \\ WITH YERB MATE NOT JUST TO MAKE CHIMARRÃO! CURRENT SITUATION AND INNOVATION PERSPECTIVES ON MATE SECTOR OF NORTH PLATEAU CATARINENSE}

Among the different meanings attributed to innovation, one of them is the concept of innovation as the business capability to introduce new products on the market. Starting from this understanding it is possible to conjure that the diversity and quantity of products whereby a productive sector operates can be taken as an indicator of innovation. Considering yerb mate as an example, approximately one hundred products are made based on yerb mate row material, which demonstrates its potential to innovation, considering that until recently its production was limited to yerb mate to make "chimarrão" and tea. North Plateau of Santa Catarina is a region historically known due to yerb mate production. In this region are located a dozens of companies in the sector, and in more than $70 \%$ of them, yerb mate to make "chimarrão" is the only product in the market. This observation led to an investigation in the sector, in order to assess the actual conditions of innovation, and its challenges, considering advances into new yerba mate uses and new products to be introduced in the world market. The study involved consultation in Brazilian and global companies websites, in order to recognize the variety of products that utilize yerb mate as raw material, in addition to performing field research on a sample of companies in the region. The study evidenced the prevalence of phytocosmetics based on yerb mate as well as a reduced diversity of products operated by the companies, thus showing the low level of innovation in this sector. This reality points to the need for advances in regional ervateiro sector, requiring actions not only of the business sector but also on research institutions and extension installed in the region.

Keywords: Yerb mate. Innovation. Territorial Development. North Plateau of Santa Catarina.

\section{INTRODUÇÃO}

A partir de pesquisas científicas, de experimentos realizados por empresas do setor ervateiro e até mesmo fruto da curiosidade dos consumidores, é que nos últimos anos a ervamate passou a ser utilizada como matéria-prima para a industrialização de um número significativo de produtos. Essa constatação é importante, pois, sua utilização mais usual é para o preparo do tradicional chimarrão e na forma de chás.

Desde que se tenha notícia da presença de populações indígenas na região do Planalto Norte Catarinense (PNC), ou seja, mesmo antes de sua colonização, a erva-mate foi um produto de destaque. Inicialmente, foi utilizada como produto de uso familiar na forma de chás ou infusões, mais tarde, para preparar o já conhecido chimarrão (SOUZA, 1998; MAFRA, 2008; MARQUES, 2014). Com isso, há mais de oitenta anos, dezenas de empresas vêm se instalando na região do PNC, envolvidas na industrialização do produto.

Atualmente a erva-mate, movimenta um setor produtivo e industrial de destaque, tanto no Estado de Santa Catarina, como no Rio Grande do Sul e Paraná. Mesmo que o setor industrial ervateiro, do $\mathrm{PNC}$, não movimente valores monetários expressivos, visto a existência de outros setores que têm maior representatividade neste quesito, a erva-mate tem grande representatividade socioambiental e histórica regional, pela sua relação com o contexto histórico de ocupação, além do que ela representa como valor ambiental, fazendo 
parte da Floresta Ombrófila Mista, um tipo de floresta do Bioma Mata Atlântica presente na região (VIBRANS et al., 2013).

Desde o início do Século XX, já se tem conhecimento de que a erva-mate desempenhava um papel de destaque, em especial, no abastecimento de empresas, não só da região, mas de outras cidades catarinenses e até de outros estados brasileiros, para não falar do que representou nas exportações, seja no contexto regional, como estadual, nacional e internacional. Aliás, relatos históricos registram que a erva-mate motivou o surgimento de cidades no Planalto Norte Catarinense, dentre as quais, Canoinhas é uma delas (MAFRA, $2008)^{6}$.

É pela importância histórica, social, econômica e ambiental que o produto erva-mate representa para os municípios do $\mathrm{PNC}$ que vários estudos estão sendo realizados recentemente. $\mathrm{O}$ que resultou neste texto está entre eles ${ }^{7}$. Assim, o objetivo do estudo foi avaliar as condições efetivas em termos de inovação no setor industrial ervateiro do Planalto Norte Catarinense, e seus desafios futuros. Com isso, pretende-se verificar a relação entre inovação e dinamização socioeconômica, com a sua possível contribuição no desenvolvimento da região em estudo.

A relação entre inovação e dinamização socioeconômica, já vem dos autores clássicos, dentre os quais merece destaque Schumpeter (1982). O autor argumentava que o elemento motriz da evolução da economia, com impacto no processo de desenvolvimento, é a inovação, seja sob a forma de introdução de novos produtos e técnicas de produção, ou mesmo através do surgimento de novos mercados, fontes de ofertas de matérias-primas ou composições industriais. Mesmo que as abordagens neoshumpeterianas tenham avançado, apontando a importância do meio na inovação, tal argumentação não terá perdido sua importância ${ }^{8}$.

Assim, neste estudo, tomando como variável a introdução de novos bens no mercado na forma de produtos industrializados como indicador de inovação do setor produtivo de uma determinada região, partiu-se da hipótese de que um dos principais indicadores para avaliar os avanços em termos de inovação empresarial, é a evolução na diversidade de produtos que são lançados no mercado, ao longo da existência das empresas do setor. Metodologicamente, utiliza-se da pesquisa em sites da internet e na literatura, sobre usos da erva-mate como matéria-prima em produtos industrializados, além da aplicação de um instrumento de pesquisa, junto a uma amostra de empresas do setor ervateiro da região em referência.

Neste texto, registramos os primeiros resultados das investigações, sendo que algumas das evidências constatadas no estudo deverão merecer aprofundamento, podendo inclusive suscitar novas questões, a partir da análise de outras variáveis.

Dentre os resultados da investigação, ficou evidente o reduzido número de produtos que compõem o portfólio das empresas do setor industrial ervateiro no PNC, comparativamente ao que já é produzido mundialmente. Na pesquisa com as empresas, verificaram-se poucos avanços e os desafios do setor quanto à introdução de novos produtos

\footnotetext{
${ }^{6}$ Sobre o resgate da história da erva-mate na região do Planalto Norte Catarinense, além de sua importância socioeconômica, cultural e ambiental, outros estudos são referências: Souza, 1998; Bartmann, 2009; Marques, 2014.

${ }^{7}$ A investigação que resultou neste texto refere-se a um projeto de investigação denominado Os desafios da inovação empresarial: um estudo no setor industrial da erva-mate do Planalto Norte Catarinense. Outro estudo está sendo realizado, o qual pretende avançar no estudo, a partir de outras variáveis. Trata-se de um Projeto de Dissertação no Programa de Mestrado em Desenvolvimento Regional, na Universidade do Contestado (Campus Canoinhas - Santa Catarina - Brasil).

${ }^{8}$ Adiante se faz referência às abordagens neoshumpeterianas.
} 
no mercado, o que pode ser considerado um indicador negativo em termos de inovação. Por outro lado, ficam evidências a partir do estudo de que os avanços necessários exigem ações não apenas do setor empresarial, mas, em especial, das instituições de pesquisa e extensão presentes na região.

Além destas considerações introdutórias, o texto é composto por mais três partes: (i) um referencial teórico, abordando a inovação, na sua dimensão empresarial e territorial e sua relação com o desenvolvimento territorial; (ii) uma explicitação sobre os procedimentos metodológicos; (iii) uma terceira parte com os resultados da investigação, análises e prospectivas, além de considerações finais.

\section{AS DIVERSAS CONCEPÇÕES SOBRE INOVAÇÃO}

A discussão sobre a inovação empresarial exige que se reflita teoricamente sobre temas afins, tais como, a inovação e seus impactos da dinâmica empresarial, inovação territorial e sua relação com desenvolvimento territorial. Isso, pois, quando se defende a inovação, seja no setor empresarial ou mesmo na dimensão territorial, a perspectiva que se tem é que os processos inovativos contribuam, no desenvolvimento das regiões ou territórios atingidos.

\section{A DISCUSSÃO SOBRE INOVAÇÃO FOCADA NA EMPRESA E NO EMPRESÁRIO: A CONTRIBUIÇÃO DE SCHUMPETER}

Schumpeter (1982) argumentava que o elemento motriz da evolução do capitalismo seria a inovação. Afirmava Schumpeter que o indivíduo que exercita essas novas combinações, inserindo as inovações no sistema produtivo, é o inovador, ressaltando o papel do empresário inovador.

Como exemplos de inovações, Schumpeter (1982) destacava: (i) a introdução de um novo produto; (ii) a descoberta de um novo método de produção; (iii) a abertura de um novo mercado no país ou no exterior; (iv) a descoberta de uma nova fonte de matéria-prima; (v) uma nova organização de qualquer indústria, como um novo monopólio, ou fragmentação de uma posição do monopólio. Assim, o desenvolvimento, para Schumpeter, está intimamente ligado ao conhecimento tecnológico, à existência de instituições eficientes e ao espírito capitalista, ou empreendedor, do empresário.

Apesar de não ser refutável sua argumentação, versões contemporâneas sobre inovação acrescentam novos elementos na relação entre inovação e desenvolvimento: por exemplo, o foco no meio ou ambiente. 


\section{AS ABORDAGENS NEOSCHUMPETERIANAS SOBRE INOVAÇÃO E DESENVOLVIMENTO: O FOCO NO MEIO}

As abordagens neoschumpeterianas avançam no entendimento da relação entre inovação e desenvolvimento, enfatizando que o desenvolvimento não necessariamente acontece por rupturas radicais, podendo se dar de forma adaptativa e progressiva, destacando o papel do aprendizado no processo de aprendizagem, do conhecimento tácito e da rotina nos processos inovadores. Da mesma forma, a figura isolada do empresário, central no modelo original de Schumpeter, é menos enfatizada em favor das instituições de pesquisa e desenvolvimento, na inovação em produtos e processos (DALLABRIDA, 2010).

Com essa concepção de inovação, destacam-se abordagens que se referem ao meio inovador, às regiões inteligentes e territórios inovadores. Tais abordagens sustentam-se na defesa de que a inovação não é um fenômeno de caráter individual, que ocorra somente no interior das empresas, senão coletivo. Além disso, a inovação seria promovida pelo entorno ou meio em que a empresa está inserida, não sendo uma resultante exclusiva nem prioritária da decisão de um empresário inovador. Não se trataria de negar a importância da empresa e empresário inovadores, senão que procurar ressaltar o papel do entorno ou meio na inovação. Ou seja, ambas as dimensões, a organizativa (empresa) e espacial (o entorno territorial), influem de forma conjunta e se complementam, ainda que a importância seja diversa segundo o tipo de empresa. Enquanto uma grande empresa tem maior capacidade para gerar inovações, inclusive quando suas relações com outras empresas e o meio circundante são escassas, a pequena empresa é mais dependente dessa rede de relações que tem com o entorno, para avançar no caminho da inovação (DALLABRIDA, 2010).

Dentre as correntes teóricas neoshumpeterianas, destacamos as principais.

\section{O MEIO INOVADOR (Millieux Innovateurs)}

As primeiras publicações sobre meio inovador resultam de estudos realizados no Groupe de Recherche sur les Millieux Innovateurs (GREMI), liderados inicialmente por Aydalot (1986), compreendendo também outros pesquisadores, tais como, Camagni (1995) e Maillat (1995; 2002). Os autores referidos mostraram estar em curso um processo de transformação das hierarquias espaciais não compatível com as teorias dominantes do crescimento desigual, baseadas, por exemplo, em esquemas do tipo centro-periferia. Complementarmente, afirmavam que o retrocesso de algumas tradicionais regiões centrais e a emergência de processos de dinamismo continuado em regiões periféricas ou semiperiféricas tornou claro que as teorias espaciais dominantes poderiam explicar as hierarquias urbanas existentes, mas não a sua transformação, isto é, não explicavam os processos de desenvolvimento com gênese no território. Já Crevoisier (1993), sintetiza, afirmando que os meios geram inovações fundamentais para seu avanço, ou seja, que o sucesso nas trajetórias de desenvolvimento de certas regiões resulta de suas capacidades intrínsecas de fabricar novos produtos, adotar novos processos produtivos, bem como, assumir configurações organizacionais e institucionais inovadoras.

Assim, a empresa não seria o agente inovador isolado, passando a ser parte do meio que a faz agir. Portanto, partindo dessa compressão, os comportamentos inovadores não são nacionais, mas territoriais e o que caracteriza os meios inovadores não é a dotação de

DRd - Desenvolvimento Regional em debate (ISSNe 2237-9029) 
atributos naturais ou de localização, mas, sobretudo a densidade do seu tecido social, ou seu capital relacional (MAILLAT, 1995).

Para Maillat, Quèvit e Senn (1993), o meio inovador envolve os seguintes elementos constituintes: (1) um ambiente espacial com certa homogeneidade de comportamento dos atores e uma mesma cultura técnica, não possuindo fronteiras estabelecidas, aproximando-se mais da noção de território do que de região; (2) um conjunto de atores dotados de autonomia decisional e fortemente ancorados na realidade socioeconômica local (empresas, instituições de formação e centros de I\&D); (3) elementos materiais (empresas, equipamentos, infraestruturas) e imateriais (normas, valores, saber-fazer), bem como, elementos institucionais (formas de organização do poder público e da sociedade civil) minimamente integrados; (4) uma lógica de interação, ou seja, um capital relacional regulador do comportamento dos atores e promotor das dinâmicas locais de valorização dos recursos existentes; (5) uma lógica de aprendizagem, capacitando atores para a redefinirem e reconfigurarem os seus comportamentos, ajustando-os na medida em que se transforma o meio externo, em especial, no nível dos mercados e da tecnologia.

Em síntese, a abordagem sobre meios inovadores sustenta-se na tese de que a inovação tem um caráter coletivo, resultando, em especial, de fatores sócio-histórico-culturais, econômicos e ambientais ancorados num determinado meio, o território.

\section{AS REGIÕES INTELIGENTES E OS TERRITÓRIOS INOVADORES}

Do debate recorrente sobre conhecimento e competitividade territorial, de economistas e geógrafos, surgem duas abordagens, que apesar de terem origens diferentes, se complementam: regiões inteligentes e territórios inovadores (DALLABRIDA, 2010).

O conceito de região inteligente surge na sequência das abordagens sobre meios inovadores, centrado na dialética inovação e território, bem como nas dinâmicas interativas de aprendizagem. Foi Florida (1995) quem primeiro sugeriu o conceito região inteligente (learning region), para referir-se às regiões ou territórios capazes de funcionarem como coletores e repositórios de conhecimentos e ideias e de proporcionarem o ambiente e as infraestruturas facilitadoras dos fluxos de conhecimentos, ideias e práticas de aprendizagem.

Segundo Ferrão (1996), a noção de região inteligente apresenta quatro aspectos de interesse e utilidade para o aprofundamento da relação entre inovação e desenvolvimento territorial: (1) centra o debate em torno das condições territoriais de desenvolvimento, complementando as visões que valorizam a ótica dos impactos territoriais; (2) cria uma matriz que permite integrar grande parte do patrimônio recente das diversas ciências regionais, assegurando coerência e uma finalidade clara; (3) defende uma análise preocupada em entender de forma sistemática as práticas dos diversos atores (indivíduos e coletivos) no quadro de comunidades territoriais específicas; (4) fornece argumentos favoráveis ao reforço da importância das políticas de base territorial.

A alusão atribuída aos territórios inteligentes reafirma a importância de se gerar ou incorporar conhecimentos necessários para atribuir valor de forma eficiente e racional aos seus recursos e ativos. De outra parte, impõe-se uma progressiva identificação e incorporação dos recursos e ativos territoriais às lógicas socioeconômicas, reafirmando a tese de que todo o

DRd - Desenvolvimento Regional em debate (ISSNe 2237-9029) 
processo de desenvolvimento requer a utilização imaginativa, racional, equilibrada e dinâmica dos bens patrimoniais de um território, com sua valorização, tornando-se a base do desenvolvimento territorial (CARAVACA; GARCÍA, 2009) ${ }^{9}$. Caravaca e García (2009, p. 37), afirmam:

Deste modo, parece que somente deveriam ser qualificados como inteligentes aqueles territórios que, utilizando seus próprios recursos de uma forma ambiental, social e economicamente eficiente, consigam gerar verdadeiros processos de desenvolvimento territorial integrado.

Caravaca e García (2009) afirmam que em meio às múltiplas tensões e contradições a que as sociedades atuais precisam fazer frente, na sociedade da informação e do conhecimento, torna-se cada vez mais importante a forma como se articulam os distintos âmbitos territoriais no espaço global de fluxos e redes. Nesse contexto, a capacidade inovadora tem viabilizado a inserção de empresas e territórios no espaço mundial, inserindose em elos da cadeia produtiva e de distribuição que permitam maior agregação de valor aos seus produtos e serviços, enquanto outros permanecem marginalizados ou até excluídos.

\begin{abstract}
A inovação, entendida, pois, tanto desde a perspectiva econômica como desde a vertente social e institucional, se converte deste modo em um importante fator que condiciona não só o dinamismo econômico senão também e sobretudo o desenvolvimento territorial (CARAVACA; GARCÍA, 2009, p. 26).
\end{abstract}

Quanto à inserção dos espaços territoriais no espaço global, Maillat (2002) nos relembra que tal inserção depende de qual lógica se submetem os sistemas produtivos territoriais: a lógica e a territorial. As empresas que atuam sob a lógica funcional são organizadas de maneira hierárquica, vertical, nas quais as decisões originam-se da direção central, na maioria dos casos, situadas nos grandes centros internacionais. Estas repartem geograficamente suas diferentes funções, de maneira a diminuir custos de transporte, níveis de fiscalização, utilizar-se de benefícios fiscais, etc. Os territórios em que estão implantadas tais empresas tornam-se lugar de passagem, desempenhando um papel passivo. Ao contrário, a lógica territorial tem por objetivo a territorialização da empresa, ou seja, sua inserção no sistema territorial de produção. Nestes casos, as empresas estão organizadas em rede (clusters), de modo horizontal, com o meio orquestrando o sistema. As empresas mantêm relações de cooperação/concorrência, gerando sinergias e complementaridades territoriais. $\mathrm{O}$ território desempenha assim papel ativo e as empresas são enraizadas territorialmente e contribuem para seu desenvolvimento.

É a partir deste debate teórico que autores como, Méndez (2002) introduzem o conceito de território inovador. O conceito de inovação, para o autor, é entendido como a capacidade de gerar e incorporar conhecimentos para dar respostas criativas aos problemas do presente. Assim, é possível referir-se ao território inovador, fazendo referência aos âmbitos espaciais em que seus atores e instituições forem capazes de gerar e incorporar conhecimentos para dar respostas criativas aos desafios que se lhes apresentam em cada momento da história. Segundo o autor, o padrão de desenvolvimento de um território inovador precisa atender às

\footnotetext{
${ }^{9}$ Considera-se que o sentido atribuído ao termo "bens patrimoniais" de um território é o mesmo que outros autores atribuem ao referir-se ao "capital territorial" ou "patrimônio territorial". Ou seja, ambos os termos referem-se ao conjunto de ativos e recursos, materiais e imateriais, genéricos e específicos, disponíveis em um determinado território. Em Dallabrida (2016), os elementos constitutivos do patrimônio territorial são considerados referentes para as pessoas que habitam determinado território, que, ao mesmo tempo as identificam e servem como potencialidades no processo de planejamento do futuro desejado.
} 
características de um desenvolvimento territorial integrado, incluindo as dimensões econômicas do desenvolvimento, mas também, e com o mesmo destaque, as dimensões sociais, ecológicas, culturais, ético-políticas e a ordenação territorial. Um território inovador, então, é aquele que avança a partir desta estratégia prioritária em seu caminho para o desenvolvimento.

Portanto, as duas abordagens, regiões inteligentes e territórios inovadores, remetem à noção de inovação territorial, não apenas como uma simples relação entre inovação e desenvolvimento, tendo como premissa preferencial a de que a inovação não ocorre exclusiva ou preferencialmente na empresa, sim resulta das condições do meio e de processos de aprendizagem social que ocorrem nos territórios.

\section{SISTEMAS REGIONAIS E NACIONAIS DE INOVAÇÃO}

Segundo argumenta Santos (2009), há um reconhecimento, atualmente, de que as dinâmicas de inovação advêm da gestação de recursos cada vez mais dependentes da realidade socioeconômica territorial, da criação de ativos específicos e do potencial criativo dos agentes do desenvolvimento. Assim sendo, a noção de sistema regional de inovação faz referência aos instrumentos para captar, incubar e promover conhecimento, adequando-o às modernas necessidades dos sistemas produtivos locais. Assim, a promoção de arranjos institucionais e organizacionais voltados à inovação tem sido mais frequente, assumindo que a competitividade e sustentabilidade regionais tem uma forte relação com a capacidade das empresas e instituições de inovar, pelo incremento da sua base de conhecimentos. A base conceitual e metodológica dos sistemas regionais de inovação filia-se no ideário proveniente da teoria dos sistemas e da economia da inovação, reconhecendo que a tecnologia e a inovação dependem de um complexo socioeconômico de interações (SANTOS, 2009).

Lundvall (1992) e Nelson (1993) introduzem o conceito de sistemas de inovação, destacando que o processo de inovação caracteriza-se, fundamentalmente, pelo aprendizado interativo. São centrais os conceitos de aprendizado contínuo e interações entre os agentes. Segundo esta concepção, conhecimento e aprendizado são, respectivamente, recurso e processo fundamentais na economia e na sociedade atuais. Dessa forma, segundo o conceito de sistemas de inovação, a inovação e o desenvolvimento originam-se de condições particulares, sociais, institucionais e de características histórico-culturais. São os elementos e as relações presentes em determinado sistema que poderão determinar a capacidade de aprendizado de um país, região ou localidade, e assim, a capacidade de inovação e de adaptação às mudanças do ambiente. Com isso, o conceito faz referência a sistemas locais, regionais e nacionais de inovação. Assim um sistema de inovação compreende um determinado sistema produtivo e o meio político institucional envolvente, indo da escala regional à nacional, até à internacional (LUNDVALL, 1992; NELSON, 1993).

Tais abordagens ressaltam o caráter sistêmico das inovações, relacionando-se ao potencial de transcender a visão linear da mudança tecnológica, segundo a qual, necessariamente, parte-se das atividades de pesquisa e desenvolvimento, passando pela inovação e difusão, para chegar-se ao incremento da produtividade. A abordagem sistêmica está por trás da noção de que o desenvolvimento somente é possível através de uma estratégia que reúna inovações tecnológicas, organizacionais e institucionais e que integre aspectos econômicos, sociais e ecológicos (DALLABRIDA, 2010). 


\section{A CONTRIBUIÇÃO DE OUTRAS ABORDAGENS QUE RELACIONAM INOVAÇÃO E DESENVOLVIMENTO À PERSPECTIVA TERRITORIAL}

São muitos os autores que, somando-se aos já referenciados, estabelecem uma relação causal entre inovação, desenvolvimento e o ambiente empresarial e territorial.

Boisier (2011) defende a dependência territorial dos processos sociais, em especial, de desenvolvimento, admitindo a necessidade de intervenção humana. Para o autor, o desenvolvimento consiste na criação de condições de entorno para que os indivíduos potenciem seu status de pessoa humana, apontando como referência as noções de dignidade, o indivíduo como sujeito da sua história, à possibilidade de convivência digna e pacífica, incluindo, também a dimensão espiritual. Por fim, o autor ressalta algumas condições para o desenvolvimento que atenda a dimensão de pessoa humana: (i) uma matriz produtiva com forte incorporação de progresso técnico; (ii) uma matriz social bem dotada de capital social; (iii) uma matriz política com elevado capital cívico; (iv) uma matriz científico-tecnológica com possibilidade de expandir-se; (v) uma matriz ecológica que aponte a um padrão de desenvolvimento sustentável ambientalmente; (vi) uma matriz cultural produtora de uma clara identidade territorial.

Outro autor, Barquero (2011), afirma que nas últimas décadas, com cada vez maior frequência as empresas e as organizações direcionam suas decisões de investimento e localização nos territórios mais dinâmicos e inovadores, convertendo-os em lugares estratégicos de crescimento econômico e progresso social. Com isso, os processos de transformação e mudanças não são produzidos de maneira uniforme nos territórios. Ocorrem nos espaços inovadores que exercem a liderança nos processos de desenvolvimento, pelo fato de serem capazes de instrumentar suas decisões através de sistemas criativos de produção, de organização e de interação. "O efeito resulta particularmente positivo nas cidades e regiões criativas já que abrem oportunidades crescentes às empresas inovadoras em todo o tipo de atividades" (p. 87).

Por fim, cabe destacar a referência que alguns autores fazem à categoria conceitual inteligência territorial. Farinós (2011) se refere à inteligência territorial como o conhecimento necessário para poder compreender as estruturas do sistema territorial e suas dinâmicas, assim como o conjunto de instrumentos empregados pelos atores públicos e privados para produzirem, utilizarem e compartilharem este conhecimento em favor de um desenvolvimento territorial sustentável. "Partindo desta perspectiva a inteligência territorial é uma ferramenta para a governança territorial e a participação a força motriz da mesma" (p. 46). Para o autor, se requer a existência de um adequado capital intelectual de inteligência territorial e de um suficiente nível de conhecimento disponível entre os atores implicados no desenvolvimento territorial.

Já, para Girardot (2009) a inteligência territorial é um meio para os investidores, os atores e a comunidade territorial adquirir um melhor conhecimento do território, no entanto, também, de fazer parte do processo de desenvolvimento. Para o autor, a apropriação de tecnologias da informação e da comunicação é uma etapa indispensável para que os atores introduzam um processo de aprendizagem que lhes permita atuar de maneira pertinente e eficiente. A inteligência territorial é útil para ajudar os atores territoriais a projetar, definir, animar e avaliar as políticas e ações de desenvolvimento territorial sustentável. 


\section{INOVAÇÃO E DESENVOLVIMENTO TERRITORIAL: UMA SÍNTESE}

Como visto, as diferentes abordagens sobre inovação empresarial e territorial, resumidamente, apontam para dois pressupostos, não necessariamente contraditórias, mas complementares. Primeiro, a visão schumpeteriana de inovação, ressaltando que o conhecimento tecnológico, a existência de instituições eficientes e o espírito empreendedor do empresário são decisivos para o sucesso empresarial, com reflexos positivos no desenvolvimento. Já as abordagens neoshumpeterianas sobre inovação, defendem que o desenvolvimento não necessariamente acontece por rupturas radicais, podendo se dar de forma adaptativa e progressiva, destacando o papel da aprendizagem, com o que a inovação não é um fenômeno de caráter individual, mas coletivo.

Ou seja, ambas as dimensões, a organizativa (empresa) e espacial (o entorno territorial), influem de forma conjunta e se complementam. Portanto, tais abordagens, remetem à noção de inovação territorial, com o que a inovação não ocorre exclusiva ou preferencialmente na empresa, sim resulta das condições do meio e de processos de aprendizagem social que ocorrem nos territórios. E essas são condições essenciais para a qualificação do processo de desenvolvimento (DALLABRIDA, 2010).

Sobre desenvolvimento, assumimos a acepção expressa em Dallabrida (2015, p. 235):

O desenvolvimento territorial é entendido como um processo de mudança continuada, situado histórica e territorialmente, mas integrado em dinâmicas intraterritoriais, supra territoriais e globais, sustentado na potenciação dos recursos e ativos (materiais e imateriais, genéricos e específicos) existentes no local, com vistas à dinamização socioeconômica e à melhoria da qualidade de vida da sua população.

Portanto, o que se almeja quando fazemos referência ao desenvolvimento é que as mudanças resultantes da forma de ocupação dos territórios resultem não apenas na dinamização socioeconômica, mas, essencialmente, na melhoria da qualidade de vida para sua população. E falar de inovação empresarial em um setor produtivo que tem importância regionalmente, como o caso do setor ervateiro no PNC, é falar da possibilidade de qualificação do processo de desenvolvimento da referida região. Mas como está o posicionamento desse setor empresarial do PNC? ${ }^{10}$ Essa é uma interrogação que motivou as investigações das quais resultaram este texto.

\section{PROCEDIMENTOS METODOLÓGICOS}

O processo de investigação esteve focado no estudo do setor empresarial ervateiro de municípios do Planalto Norte Catarinense ${ }^{11}$. Na Figura 1, está a localização dos municípios que compõem este recorte territorial, nos quais estão localizadas as empresas que foram objeto de pesquisa.

\footnotetext{
${ }^{10}$ Salientamos que a resposta a esta questão exige muito mais investigações. Nesta, daremos um primeiro passo.

${ }^{11}$ Considerando que a caracterização socioeconômica do PNC é tema de artigos que compõem a presente edição da revista DRd, não aprofundaremos aqui o tema.
} 
Figura 01 - Localização dos municípios que compõem a região do Planalto Norte Catarinense

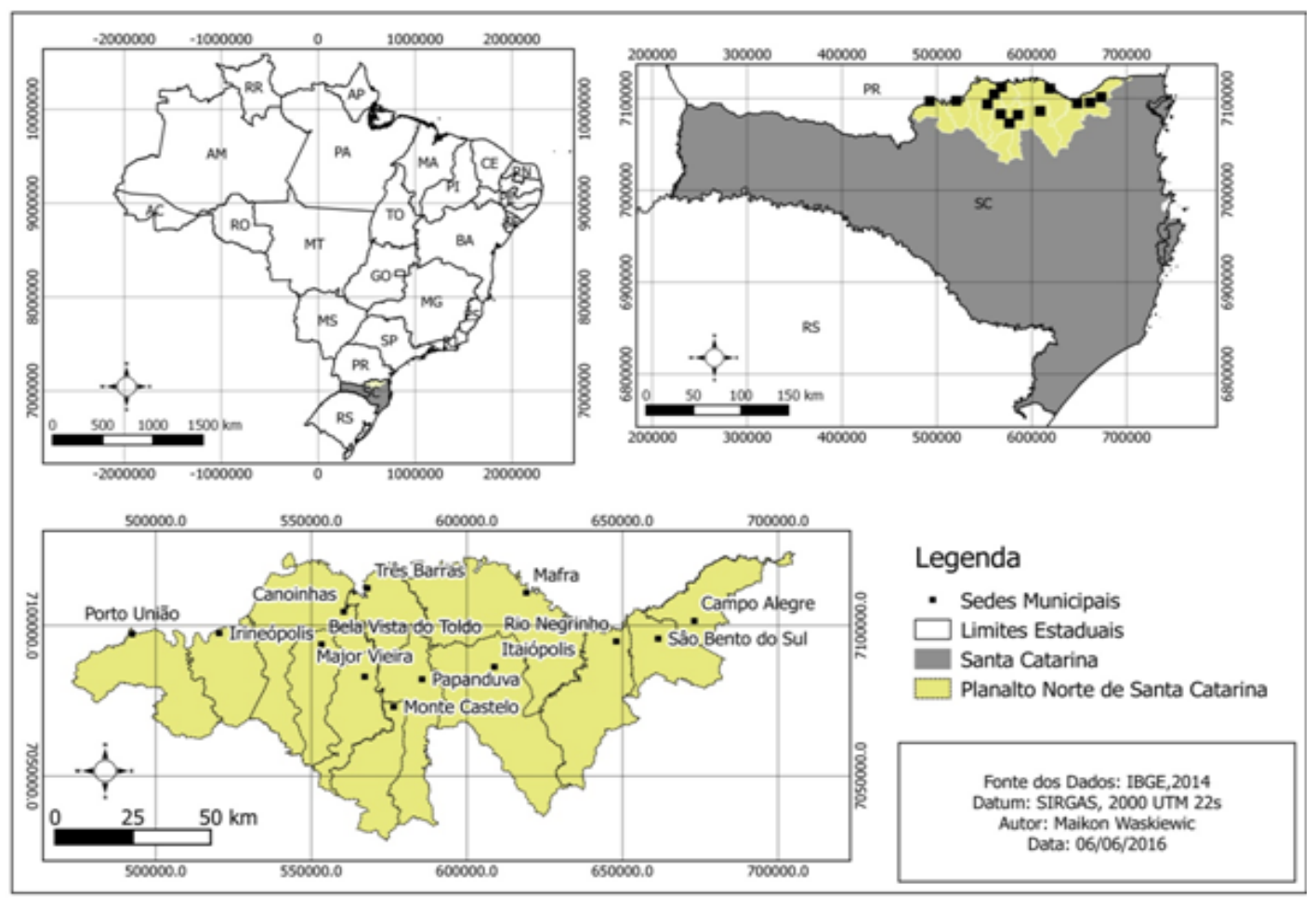

Fonte: Elaboração de Maikon Waskiewic, a partir da base de dados do IBGE

Para atender a um dos objetivos específicos da investigação - conhecer os principais usos da erva-mate como matéria-prima industrial -, foi realizada uma pesquisa em sites de todas as empresas que se teve acesso, seja do Estado de Santa Catarina, de outros estados brasileiros e do exterior. Nesse aspecto, o limite do universo pesquisado foi a possibilidade de acesso por meio de sites de busca na internet, no período da pesquisa, janeiro até maio de 2016. O critério de pesquisa foi acessar empresas que produzissem outros produtos, além da erva-mate para chimarrão e chás.

Nos municípios do PNC consta a existência de vinte e seis empresas ervateiras ${ }^{12}$. Esse número foi apurado em pesquisa feita nos arquivos das prefeituras dos municípios da região, no mês de maio/2016, por meio de consulta aos responsáveis pelo cadastro industrial. Portanto, o número de empresas no PNC é um dado que demonstra a importância desse setor para a economia regional.

Com o propósito de averiguar questões referentes à inovação no setor empresarial ervateiro do PNC, elaboramos um instrumento de pesquisa, com questões estruturadas e semiestruturadas. A escolha das empresas para a pesquisa foi aleatória. Fizemos o convite para a participação a todas as empresas dos treze municípios do PNC, no total de 26. A partir da manifestação do interesse das empresas em responder a pesquisa, enviamos formulário para 17 empresas. Destas, no período estabelecido, 11 empresas retornaram com a resposta ao

\footnotetext{
${ }^{12} \mathrm{O}$ dado é aproximado, pela falta de estatísticas mais atualizadas disponíveis para consulta nas prefeituras, além do fato de que ocorre anualmente fechamento ou abertura de novas empresas, em especial as de pequeno tamanho.
} 
instrumento de pesquisa. Com base nas respostas dessa amostra de empresas é que foram compilados os dados e feitas as análises.

Assim, foram pesquisadas empresas dos seguintes municípios catarinenses: Bela Vista do Toldo, Campo Alegre, Canoinhas, Itaiópolis, Monte Castelo e São Bento do Sul. O município com maior número de empresas pesquisadas foi Canoinhas. Na sequência, apresentamos os resultados do presente estudo, nesse primeiro estágio de investigação.

\section{RESULTADOS DA INVESTIGAÇÃO E ANÁLISES}

Inicia-se a apresentação dos resultados da investigação, pela descrição do que resultou da pesquisa sobre produtos que utilizam a erva-mate como matéria-prima.

Pela pesquisa sobre a variedade de produtos industrializados, que utilizam a erva-mate como matéria-prima foram obtidos os seguintes resultados: (i) acessou-se a um total de sessenta e duas empresas, no Brasil (57) e no exterior (5), que produzem e/ou comercializam produtos à base de erva-mate, não incluindo neste número, empresas que produzissem apenas erva-mate para chimarrão, além de erva para chás e tererê; (ii) a pesquisa chegou a uma lista extensa de produtos, como é possível verificar no Quadro 1.

Quadro 1 - Listagem de produtos industrializados tendo a erva-mate como matéria-prima

\begin{tabular}{|c|c|c|}
\hline Categoria & Produto(s) & Uso/características \\
\hline Alimentos & Chocolate & Chocolate com erva-mate e cacau \\
\hline Alimentos & Extrato líquido de erva-mate & Para preparo de Alimentícios \\
\hline Alimentos & Farimate & Farinha de trigo com adição de erva-mate \\
\hline Alimentos & Sorvete de erva-mate & Alimento gelado na forma de sorvete \\
\hline Bebida & Absinto & Bebida com teor alcoólico \\
\hline Bebida & $\begin{array}{l}\text { Bebida à base de mate, adoçada com açúcar } \\
\text { de cana ou de estévia }\end{array}$ & Bebida para consumo em geral \\
\hline Bebida & Bebida hidroeletrolítica & Bebida para atletas \\
\hline Bebida & Cerveja à base de erva-mate & Bebida com teor alcoólico \\
\hline Bebida & Champagne de erva-mate & Bebida gaseificada à base de erva-mate \\
\hline Bebidas & Chás Solúveis em Pó & Para preparo de sucos e bebidas \\
\hline Bebidas & Concentrado de Erva-Mate Orgânico & Para preparo de sucos e bebidas \\
\hline Bebida & Destilado & $\begin{array}{l}\text { Bebida destilada para consumo com teor } \\
\text { alcoólico }\end{array}$ \\
\hline Bebida & Drink Energético orgânico & $\begin{array}{l}\text { Drink energético natural à base de erva-mate } \\
\text { orgânica }\end{array}$ \\
\hline Bebida & Energy Drink Energético & Bebida energética à base de erva-mate \\
\hline Bebida & Mate expresso tostado e natural & Bebida, para uso como chá \\
\hline Bebida & Mate solúvel & Chá solúvel de erva-mate \\
\hline Bebida & Mate Verde Instantâneo & Bebida, para uso como chá \\
\hline Bebida & Preparado Líquido de Chá Mate & Para preparo de sucos e chás \\
\hline Bebida & Suco com erva-mate & Sucos \\
\hline Bebida & Tererê líquido com sabores de frutas & Sucos para tomar \\
\hline Bebidas & Xarope de Chá Mate Orgânico & Para preparo de sucos e bebidas \\
\hline Cosméticos & Body Splash & Creme para o corpo \\
\hline Cosméticos & Condicionador de cabelos & Condicionador de cabelos \\
\hline Cosméticos & Creme Hidratante Corporal & Previnem o envelhecimento da pele \\
\hline Cosméticos & Creme hidratante Facial & Ação revitalizante e tônus muscular da pele, \\
\hline
\end{tabular}




\begin{tabular}{|c|c|c|}
\hline Cosmético & Creme Hidratante para mãos & Uso nas mãos \\
\hline Cosmético & Creme Hidratante para pés & Uso nos pés \\
\hline Cosméticos & Creme para pentear & Para os cabelos \\
\hline Cosméticos & Desodorante colônia & Desodorante corporal \\
\hline Cosméticos & Extrato oleoso de erva-mate & $\begin{array}{l}\text { Produto lipossolúvel para preparo de } \\
\text { cosméticos e produtos de limpeza }\end{array}$ \\
\hline Cosméticos & Extratos líquidos hidroalcoólicos & Para uso em produtos de uso capilar \\
\hline Cosméticos & Fitoblend de Saponinas & $\begin{array}{l}\text { Mix de extratos ervas, com o mate, para } \\
\text { produção de cosméticos }\end{array}$ \\
\hline Cosméticos & Fitoglicerinado de Erva-Mate & $\begin{array}{l}\text { Composto básico a base erva-mate para preparo } \\
\text { de cosméticos }\end{array}$ \\
\hline Cosméticos & Fluído Termoprotetor & Protetor de fio de cabelo \\
\hline Cosméticos & Geleia Hidratante & Hidratantes nutritivo e protetor da pele \\
\hline Cosméticos & Glicólicos de erva-mate & $\begin{array}{l}\text { Produtos hidrossolúveis: composto básico para } \\
\text { preparo de cosméticos }\end{array}$ \\
\hline Cosméticos & Gloss Labial & Uso nos lábios \\
\hline Cosméticos & Loção de Limpeza demaquilante & Limpar e renovar as peles normais e secas \\
\hline Cosméticos & Manteiga Esfoliante & $\begin{array}{l}\text { Propriedades tonificantes e adstringentes e } \\
\text { micropartículas de limpeza }\end{array}$ \\
\hline Cosméticos & Máscara Capilar Biorreconstrutora & Reconstrução da estrutura capilar \\
\hline Cosméticos & Óleo bifásico & Para o corpo \\
\hline Cosméticos & Óleo Hidratante de Banho & $\begin{array}{l}\text { Produto com flavonoides que previnem o } \\
\text { envelhecimento da pele }\end{array}$ \\
\hline Cosméticos & Polpa Cremosa Hidratante & Propriedades revitalizantes e energizantes \\
\hline Cosméticos & Sabonete Esfoliante Facial & Para esfoliação profunda na pele \\
\hline Cosméticos & Shampoo Biorreconstrutor & $\begin{array}{l}\text { Limpeza e fortalecimento dos fios danificados e } \\
\text { quimicamente tratados }\end{array}$ \\
\hline Cosméticos & Shampoo fortalecedor & Shampoo Capilar \\
\hline $\begin{array}{l}\text { Higiene e } \\
\text { limpeza }\end{array}$ & Água de Cheiro para Tecidos & Para perfumar roupa \\
\hline $\begin{array}{l}\text { Higiene e } \\
\text { limpeza }\end{array}$ & Aromatizante de ambiente & Para perfumar ambiente \\
\hline $\begin{array}{l}\text { Higiene e } \\
\text { limpeza }\end{array}$ & Desodorante & Uso pessoal \\
\hline $\begin{array}{l}\text { Higiene e } \\
\text { limpeza }\end{array}$ & Difusor de aromas & Para perfumar ambiente \\
\hline $\begin{array}{l}\text { Higiene e } \\
\text { limpeza }\end{array}$ & Espuma de Banho & Limpeza e hidratação \\
\hline $\begin{array}{l}\text { Higiene e } \\
\text { limpeza }\end{array}$ & Espuma de barbear & Para barbear \\
\hline $\begin{array}{l}\text { Higiene e } \\
\text { limpeza }\end{array}$ & Gel pós-barba & Para barbear \\
\hline $\begin{array}{l}\text { Higiene e } \\
\text { limpeza }\end{array}$ & Loção Pós-Sol & Para a pele \\
\hline $\begin{array}{l}\text { Higiene e } \\
\text { limpeza }\end{array}$ & Mascara facial & Capilar \\
\hline $\begin{array}{l}\text { Higiene e } \\
\text { limpeza }\end{array}$ & Pasta esfoliante para os pés & Tonificantes e adstringentes \\
\hline $\begin{array}{l}\text { Higiene e } \\
\text { limpeza }\end{array}$ & Sabonete em barra & Corporal e limpeza em geral \\
\hline $\begin{array}{l}\text { Higiene e } \\
\text { limpeza }\end{array}$ & Sabonete líquido & Para mãos \\
\hline $\begin{array}{l}\text { Higiene e } \\
\text { limpeza }\end{array}$ & Sal de banho & Relaxantes e antiestresse \\
\hline
\end{tabular}


Com erva-mate não se faz só chimarrão! Situação atual e perspectivas de inovação no setor ervateiro do Planalto Norte Catarinense

\begin{tabular}{|l|l|l|}
\hline $\begin{array}{l}\text { Higiene e } \\
\text { limpeza }\end{array}$ & Vela aromática & Vela aromática para ambientes \\
\hline $\begin{array}{l}\text { Higiene e } \\
\text { limpeza }\end{array}$ & Vela de massagem & Nutrem, tonificam e hidratam a sua pele \\
\hline Saúde & Erva-mate em cápsulas & $\begin{array}{l}\text { Diminuição do colesterol e funcionamento do } \\
\text { intestino }\end{array}$ \\
\hline Saúde & Florais & Uso interno \\
\hline $\begin{array}{l}\text { Saúde e } \\
\text { Alimento }\end{array}$ & Extrato fluído de erva-mate & Usos diversos \\
\hline $\begin{array}{l}\text { Saúde e } \\
\text { Alimento }\end{array}$ & Extrato glicólico de erva-mate & Usos diversos \\
\hline $\begin{array}{l}\text { Saúde e } \\
\text { Alimento }\end{array}$ & $\begin{array}{l}\text { Extrato líquido de erva-mate } \\
\text { (verde, estacionado e tostado) }\end{array}$ & Usos diversos \\
\hline $\begin{array}{l}\text { Saúde e } \\
\text { Alimento }\end{array}$ & $\begin{array}{l}\text { Extrato seco de erva-mate (com vários } \\
\text { níveis de cafeína) }\end{array}$ & Usos diversos \\
\hline $\begin{array}{l}\text { Saúde e } \\
\text { Alimento }\end{array}$ & $\begin{array}{l}\text { Extrato seco de erva-mate (verde, } \\
\text { estacionado e tostado) }\end{array}$ & Usos diversos \\
\hline Outros usos & Corante natural de erva-mate verde oliva & Tingimento de tecidos \\
\hline
\end{tabular}

Fonte: Dados da Pesquisa, a partir da consulta aos sites de empresas (2016)

Como é possível observar na lista de produtos o uso principal da erva-mate é na linha de bebidas, cosméticos e higiene e limpeza, e secundariamente, em alimentos e produtos para promoção da saúde.

Na Figura 2, os dados do Quadro 1 são apresentados na forma de números absolutos de produtos pertencente às diferentes classificações.

Figura 2 - Classificação dos produtos do Quadro 1

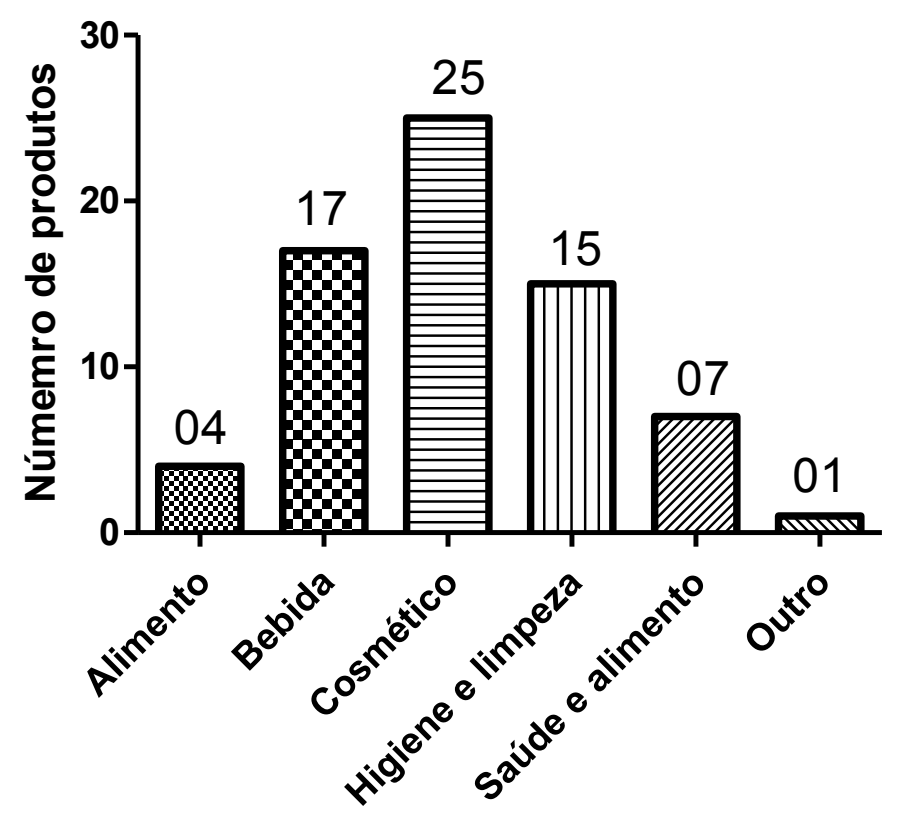

Fonte: Dados da Pesquisa, a partir da consulta aos sites de empresas (2016)

DRd - Desenvolvimento Regional em debate (ISSNe 2237-9029) 
Através da análise destes dados é possível detectar que os elementos que caracterizam a inovação se manifestam de forma mais intensa nos segmentos de cosméticos, que nos segmentos de alimentos e bebidas. A fitocosmética se dedica ao estudo e à aplicação dos conhecimentos da ação dos princípios ativos extraídos de espécies do reino vegetal, em proveito da higiene, da estética, da correção e da manutenção de um estado normal e sadio da pele e cabelo. Este interesse na utilização de extratos de erva mate na preparação de cosméticos naturais pode ser correlacionada com evidências científicas da sua ação antioxidante, anti-inflamatória e antimicrobiana (BRAVO, GOYA e LECUMBERRI et al., 2007; LANZETTI et al., 2008) justificando assim seu emprego nesta categoria. Indo além neste tema, com a utilização das plantas nos produtos cosméticos foram desenvolvidos os cosméticos orgânicos, que são fabricados com ingredientes que seguem normas de qualidade e sustentabilidade obedecendo a normas rígidas de certificação capazes de garantir, ao consumidor final, a qualidade orgânica dos produtos adquiridos (BORGES, GARVIL, ROSA, 2013). Por isso, os orgânicos, aos poucos estão ganhando mercado, não só nos alimentos, mas agora também em cosméticos e podem ser considerados uma interessante estratégia para a inovação em cosméticos a partir da erva mate. Tendo em vista que a produção orgânica obedece às normas rígidas de certificação que exigem além da não utilização de agrotóxicos e drogas venenosas, os cuidados elementares como a conservação e a preservação de recursos naturais e condições adequadas de trabalho tendo por objetivo a sustentabilidade econômica e ecológica, um produto cosmético orgânico a partir da erva mate pode ser considerada uma estratégia de inovação e desenvolvimento do território do PNC.

Apesar de ainda pouco expressivo quando comparados às outras classificações, foi observado que existe no mercado cápsulas a base de erva mate moída que são utilizadas pela população para a diminuição do colesterol. De fato, um estudo conduzido em humanos demonstrou que a redução dos níveis de colesterol foi maior naqueles indivíduos que consumiam a erva mate juntamente com o medicamento, sugerindo assim a utilização da erva mate como nutracêutico (MORAIS et al., 2009). O termo nutracêutico vem da junção de "nutriente" e "farmacêuticos", pois os nutrientes têm a capacidade comprovada de proporcionar benefícios à saúde, como a prevenção e o tratamento de doenças (MORAES; COLLA, 2006).

Ressalte-se que, apesar das muitas possibilidades de uso da erva-mate como fitomedicamento, conforme já salientado no início do texto, nos sites pesquisados detectaramse informações apenas sobre o uso sob a forma de extrato líquido ou seco, o que, neste caso, é classificado como complemento alimentar. Isso, pois, não foi feita a consulta em laboratórios de medicamentos, nos quais seria possível identificar alguns produtos que já estejam no mercado. Para concluir, nos últimos anos a pesquisa na área de produtos naturais tem progredido devido aos avanços tecnológicos e dessa forma a avaliação da dinâmica da inovação em bionegócio (nutracêutico ou até mesmo fitomedicamento) a partir da erva mate pode ser inserida dentro da temática da inovação e desenvolvimento territorial do PNC. Apesar da existência de estudos acadêmicos, muito ainda há por ser feito, até que se vislumbre um maior uso da erva-mate como medicamento. Isso aponta para a necessidade de estudos nesta área ${ }^{13}$.

\footnotetext{
${ }^{13}$ No curso de Farmácia da Universidade do Contestado, estão sendo realizados estudos, alguns já na fase de testes em humanos, sobre efeitos terapêuticos da erva-mate. Destes e outros estudos, poderão resultar futuras inovações em novos usos da erva-mate, neste caso, na fabricação de fitomedicamentos. Um dos artigos dessa edição da DRd, trata do tema.
} 
A segunda dimensão da investigação trata da pesquisa no setor empresarial ervateiro do PNC, levantando dados e informações que pudessem apontar indicativos em relação à inovação. Como salientado, esta parte da investigação utilizou-se de um instrumento de pesquisa aplicado a uma amostra de onze empresas da região, conforme apresentado no Anexo 1.

A pesquisa realizada com empresas apurou uma série de informações e/ou dados: (i) quanto ao ano de fundação, as mais antigas foram fundadas, em 1918 e 1938; das demais, seis foram fundadas entre as décadas de 1970 e 1980, uma na década de 1990 e as mais recentes foram fundadas em 2009 e 2011; (ii) quanto à origem da erva-mate beneficiada pelas empresas, $48 \%$ provêm de municípios do PNC e outros $42 \%$ de municípios próximos, no Paraná (Figura 3); (iii) o beneficiamento ou industrialização da erva-mate para chimarrão é, majoritariamente, o produto que compõe o portfólio das empresas pesquisadas, sendo que, de forma pouco significativa, algumas empresas também produzem chás, palito ou erva-mate para tererê, com uma empresa terceirizando a produção de picolé sabor erva-mate.

Figura 3 - Origem da matéria-prima beneficiada/industrializada nas empresas pesquisadas

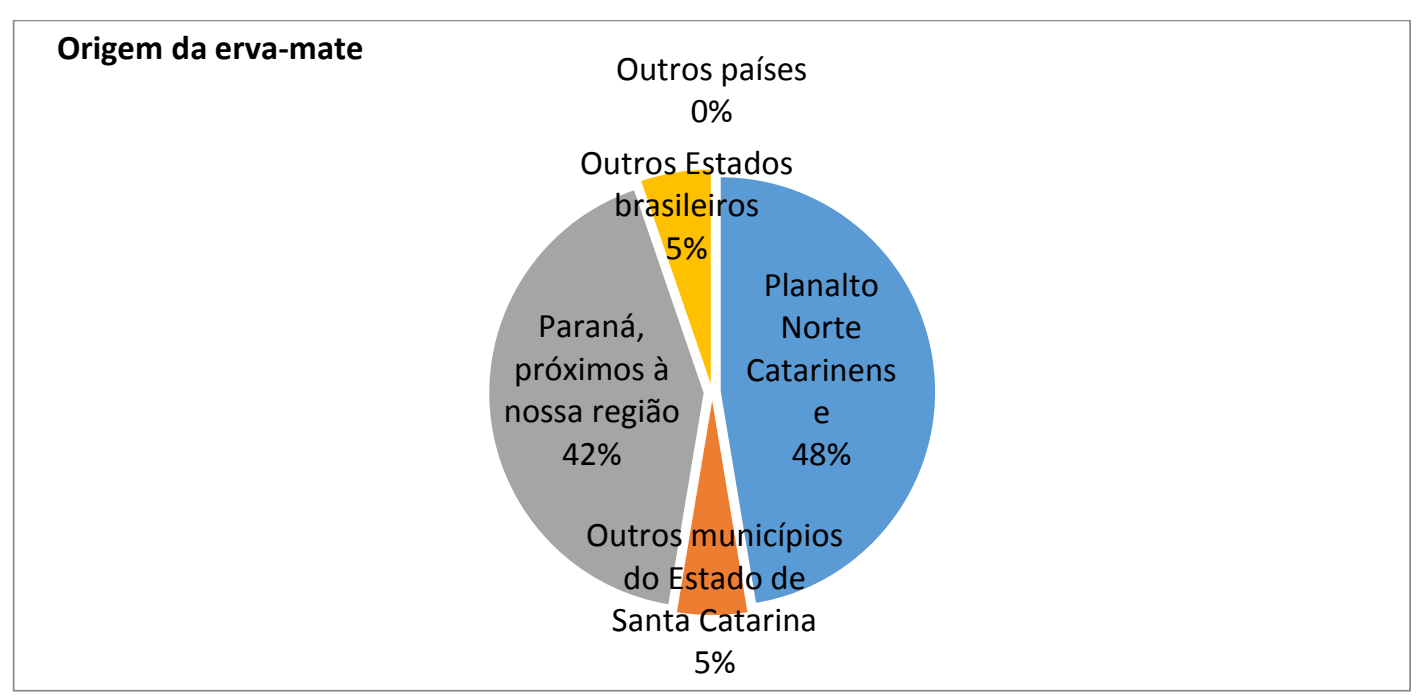

Fonte: Pesquisa (2016)

Podemos constatar que o setor industrial ervateiro do PNC tem muitos desafios a superar: (i) possuem uma pequena variedade em seu portfólio de produtos, se compararmos ao que é encontrado atualmente no mercado nacional e internacional; (ii) além da erva-mate para chimarrão, mesmo a produção dos demais produtos, na maioria das empresas, é uma iniciativa recente.

O fato positivo é que, segundo dados da amostra pesquisada, 48\% da matéria-prima erva-mate provém da própria região do PNC. Se somada com a que se origina de áreas muito próximas, o caso do Centro Sul do Paraná, recorte territorial contíguo, esse montante chega a 90\%. Essas áreas, além de se constituírem numa das maiores produtoras do Brasil, a ervamate que tem origem nelas, é considerada da melhor qualidade, somado ao fato de que tem um diferencial: mais de $80 \%$ é oriunda da extração de folhas em formações de remanescentes 
da Floresta Ombrófila Mista, podendo ser considerada uma atividade sustentável ecologicamente (MARQUES, 2014) ${ }^{14}$.

Sobre a opinião dos empresários em relação ao reduzido portfólio de produtos, $27 \%$ das empresas considera suficiente continuar trabalhando com poucos produtos, enquanto $73 \%$ delas tem interesse em diversificar a produção. Perguntados sobre se consideram que a empresa poderia atuar no mercado com mais produtos e qual o motivo que justifica não ter ampliado sua quantidade, $55 \%$ das empresas responderam que, mesmo tendo procura fora da região ou no exterior, as atividades atuais da empresa são suficientes para manter-se no mercado. Os demais respondentes afirmaram ser importante diversificarem a produção e apresentaram como justificativa a desunião entre os sócios, a questão dos baixos preços da erva-mate e a mentalidade conservadora dos dirigentes, além das poucas pesquisas sobre o tema.

Veja-se que as respostas dão indicativo de pouca dinamicidade em termos de inovação. É significativo o número de respostas que indicam certa acomodação do setor, em função de estarem conseguindo competir no mercado, mesmo sem ensejarem avanços. No entanto, as respostas, também, apontam para o reconhecimento dos desafios que precisam ser enfrentados, como o caso da diversificação da produção e novas investigações que interessa ao setor.

Já, quanto ao destino dos produtos industrializados e comercializados pelas empresas pesquisadas, o mercado consumidor regional e nacional é majoritário ainda; para cinco empresas corresponde a $100 \%$ da produção, enquanto para outras quatro, oscila entre 50 e $70 \%$. O mercado internacional como destino da produção, para uma empresa oscila entre 70 e $95 \%$, duas entre 50 e $70 \%$ e para três outras, representa menos de $50 \%$. As demais não atuam no mercado internacional. Ou seja, os dados apontam que o mercado regional e nacional consegue oportunizar certa competitividade do setor produtivo regional. Certamente, o fato das empresas da região estarem relativamente próximas a um dos maiores mercados consumidores, além do interior do estado de Santa Catarina, que é o mercado gaúcho, no vizinho estado do Rio Grande do Sul, em muito contribui para a manutenção do setor.

Questionados os representantes das empresas sobre a inovação empresarial, tivemos as seguintes respostas: (i) duas referiram que não têm inovado em nada; (ii) quatro disseram inovarem em máquinas, três em embalagens, três em programas de qualidade; (iii) duas consideraram a exportação como uma inovação; (iv) outras respostas individuais variaram, afirmando que inovam em novos pontos de venda, sua inserção em roteiros turísticos, promoção de eventos e manutenção de site atualizado; (v) no entanto, somente três empresas disseram inovar no lançamento de novos produtos. Os motivos alegados para não inovar variaram entre desunião dos sócios, pouco incentivo na produção, mente conservadora, resistência dos sócios da empresa, falta de pesquisa, de conhecimento e capacitação das pessoas envolvidas nas empresas.

Portanto, estas respostas estão entre as mais agravantes em relação ao setor quanto à inovação. Somente três empresas demonstraram estarem preocupadas com a inovação em novos produtos. As demais dimensões apontadas como ações inovadoras, o são apenas em parte, como o exemplo de embalagens e máquinas. Nestes casos, em geral, tais inovações

${ }^{14}$ Vejam-se mais dados sobre a produção ervateira regional, nos demais artigos dessa edição da DRd. 
atendem exigências do mercado quanto à qualidade dos produtos, em outros casos, atendem às exigências de adequação legal.

Sobre os fatores favoráveis ao sucesso do setor industrial da erva-mate no PNC (Figura 4), mereceram destaque a qualidade da matéria-prima (46\%), a tradição $(15 \%)$ e a disponibilidade de matéria-prima regionalmente (15\%). Outros fatores são mencionados, tais como, a existência regional da erva-mate nativa, o clima favorável e as parcerias do setor.

Em relação aos fatores favoráveis ao sucesso do setor empresarial ervateiro, constatase o reconhecimento de vantagens competitivas, como a questão do diferencial de qualidade da matéria-prima produzida próxima à região em estudo. A questão que fica é porque tais vantagens não são suficientemente capitalizadas, como o caso de que mais de $80 \%$ do produto provém de ervais nativos. Produtos com este diferencial são reconhecidos pelos consumidores dos estados do sul do Brasil, como de qualidade superior. Isso mostrado no fato de que muitas ervateiras que atuam no Rio Grande Sul vêm buscar erva-mate na região aqui destacada, para fabricar a erva-mate preferida pelos consumidores daquele estado ${ }^{15}$.

Figura 4 - Fatores considerados favoráveis ao sucesso do setor industrial da erva-mate no PNC

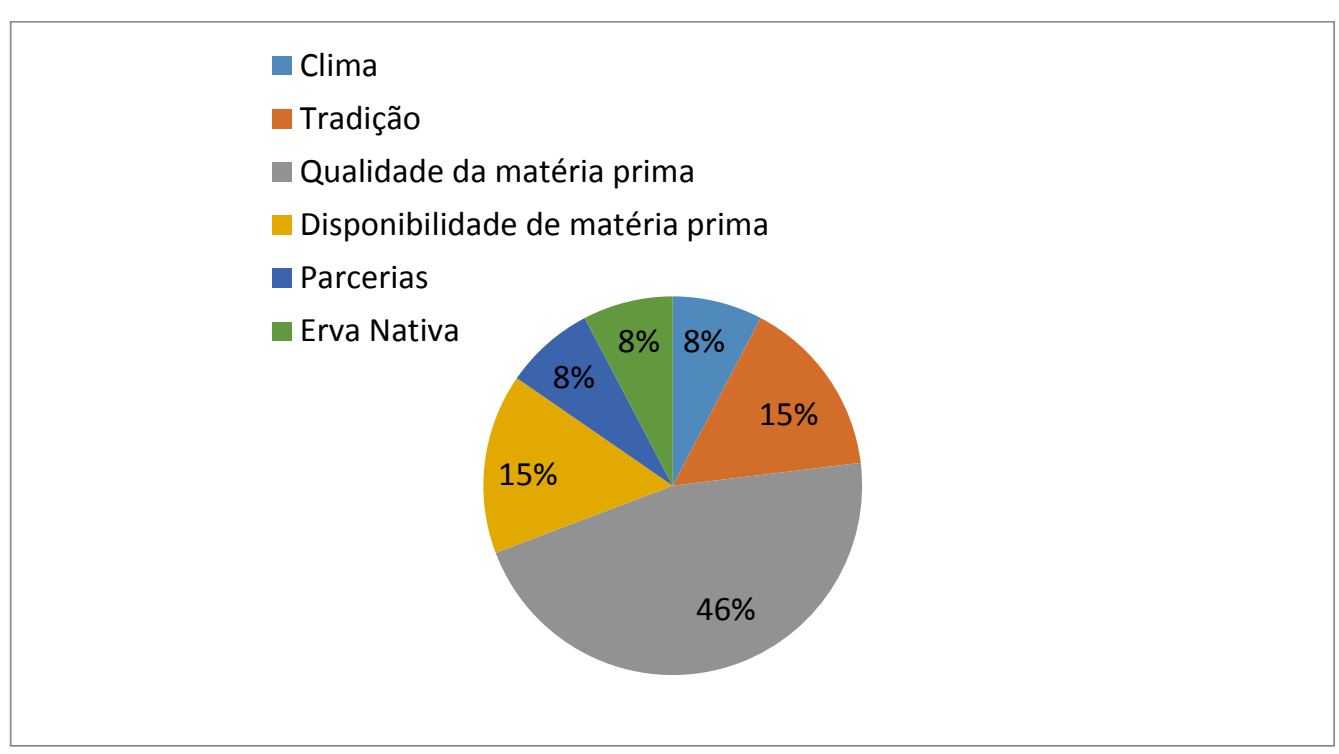

Fonte: Pesquisa (2016)

Quanto às dificuldades apontadas pelos respondentes em relação ao setor, predominou a indicação da falta de união entre o setor ervateiro regional como a principal $(23 \%$ das respostas). Vem na sequência, a concorrência (15\%) e outras respostas com percentuais entre 7 e $8 \%$, tais como: baixo incentivo e imaturidade administrativa dos órgãos públicos; falta de capacitação dos envolvidos no setor; restrições relacionadas à legislação ambiental e trabalhista; necessidade de prospectar inovações no setor e novos mercados, além do baixo preço do produto erva-mate.

\footnotetext{
${ }^{15}$ Mesmo que esse dado não tenha sido objeto de pesquisa desta investigação, tal constatação é de conhecimento público. Marques (2014) fez estudos que apontam nesta direção. No entanto, um dos artigos desta edição da DRd, apresenta dados mais precisos e atualizados.
} 
Portanto, a investigação permitiu elucidar algumas questões sobre o setor industrial ervateiro do PNC. Umas são óbvias para quem vive na região e conhece minimamente o setor. Outras permitem reflexões, algumas delas comentadas na sequência.

Analisando os dados, várias questões podem ser elencadas como significativas: (i) $76 \%$ dos inqueridos reconhecem como fator de competitividade do setor industrial do PNC, a qualidade diferenciada da matéria-prima juntamente com a tradição histórica na produção regional da erva-mate; (ii) as respostas comprovam outra vantagem competitiva do setor: poderem se abastecer da matéria-prima em áreas do PNC ou muito próximas; (iii) apesar de um número significativo de empresários referirem-se à importância de inovar, em especial, na diversificação dos produtos, contraditoriamente, mais da metade das empresas pesquisadas afirmam que as atividades atuais da empresa são suficientes para manter-se no mercado, ou seja, transparece certa acomodação do setor em termos de inovação; (iv) quanto ao destino da produção, quase a metade atua apenas no mercado regional e nacional; no entanto, é significativo o destino na produção para o mercado externo ${ }^{16}$.

Já quanto à relação da variável variedade de produtos com a inovação, podemos afirmar que o setor empresarial regional está situado numa situação que merece um reposicionamento dos empresários. Analisando os dados das 11 empresas pesquisadas, 7 delas apenas produzem erva-mate para chimarrão, sendo que apenas 4 possuem mais produtos em seu portfólio. Ao se comparar, mesmo os novos produtos das empresas regionais, com os da lista pesquisada, percebe-se que se trata de produtos que exigem pouca inovação tecnológica ${ }^{17}$.

Estas são as questões que podem ser consideradas de maior importância. Finalizemos com algumas considerações, reflexões e indicativos de novos estudos.

\section{CONSIDERAÇÕES FINAIS}

A partir das constatações e análises que os dados levantados permitem, várias considerações são procedentes, sendo que se dará destaque às mais impactantes tanto no setor, como no desenvolvimento da região.

Para avaliar o posicionamento em termos de inovação empresarial do setor industrial ervateiro do PNC, centra-se o foco numa variável: a variedade do portfólio de produtos das empresas regionais. Mesmo que se concorde que há uma limitação em se avaliar um setor apenas por uma variável, entende-se que é significativo, por duas razões: (i) o fato de que se têm empresas que atuam no mercado há quase um século; (ii) o fato de que o setor situa-se

\footnotetext{
${ }^{16}$ Mesmo que a pesquisa não tenha apurado este dado, o que poderá ser feito em estudos futuros, sabe-se por informações informais com empresários do setor, que atualmente mais de $50 \%$ da produção de erva-mate, em especial das empresas mais bem estruturadas, é exportada para países do Mercosul, Europa e Ásia. O problema é que esta exportação, na sua quase totalidade, é de produto semibeneficiado, agregando pouco valor à produção.

${ }^{17}$ Sobre a questão da inovação nas empresas, precisa-se reconhecer que, em virtude das empresas pesquisadas atenderem predominantemente o mercado regional e nacional, tal fato não exige que as mesmas inovem, pois o consumidor não busca adquirir novos e diferenciados produtos. Ou seja, pode-se conjecturar que para setores tradicionais como o ervateiro, a inovação em novos produtos não seja uma exigência essencial. É uma discussão para se aprofundar.
} 
próximo a uma região produtora de erva-mate da melhor qualidade, o que é reconhecido por empresários de outros estados, como o Rio Grande do Sul, onde há um grande consumo do produto e tem a presença significativa de empresas do setor ervateiro que, em função da qualidade diferenciada, buscam matéria-prima no PNC e Centro Sul do Parará, para fazer um mix com a erva-mate tipo especial, lá produzida. Poderíamos nos questionar: quais fatores dificultam avanços no setor ervateiro regional, considerando que o mesmo pode contar com uma vantagem competitiva da maior importância, ou seja, estar próxima a região produtora da erva-mate da melhor qualidade do Brasil?

Alguns dados da pesquisa explicam, ao menos em parte, esta importante questão. A justificativa apontada na pesquisa com as empresas, ao justificarem por que pouco inovam, pode nos dar uma pista, ao se ouvir a afirmação sobre a existência regionalmente de uma mentalidade empresarial conservadora por parte dos dirigentes de empresas, haver resistência dos sócios de empresas em inovar e ao afirmarem existir falta de conhecimento e capacitação das pessoas envolvidas no setor.

No entanto, como vimos na revisão da literatura sobre inovação, não devemos atribuir apenas ao empresário a culpa por não inovar, ao considerar que a inovação não é um fenômeno de caráter individual, senão coletivo. Ou seja, abordagens teóricas defendem que inovação seria promovida pelo entorno ou meio em que a empresa está inserida. Não se trata de negar a importância da empresa e empresário inovador, senão que ressaltar o papel do entorno e do meio institucional na inovação.

Eis uma questão que merece reflexão: quais as condições que o meio institucional regional oferece ou deixa de oferecer ao setor? Falamos das instituições de pesquisa e extensão rural, das associações representativas do setor empresarial, do apoio público oferecido ao setor, da adequabilidade da legislação que regula a atividade de extração e beneficiamento da erva-mate. Neste quesito, certamente há muito que se fazer, mesmo que, mais recentemente, algumas iniciativas estejam sendo executadas. Destaco duas: (i) pesquisas recentes realizadas no único programa de mestrado que funciona na região ${ }^{18}$; (ii) ações articuladas pelo órgão estadual catarinense de pesquisa e extensão (Epagri), com apoio do Ministério da Agricultura, Pecuária e Abastecimento, com o fim de se conseguir o reconhecimento da tradição e notoriedade da erva-mate regional, por meio da Indicação Geográfica.

De outra forma, também, nem tudo deve ser atribuído ao meio institucional. A iniciativa empresarial é fundamental para o avanço do setor. Neste sentido fica o indicativo de que o setor industrial ervateiro do PNC tem um importante desafio a superar: investir em pesquisa, qualificar seus dirigentes e funcionários, para habilitar-se a competir no mercado nacional e internacional, nos mesmos padrões de competitividade utilizados por empresas que há mais tempo inovaram, por exemplo, ampliando seu portfólio de produtos e buscando mercado para os mesmos. Isso ocorrendo, os impactos do setor ervateiro no desenvolvimento da região do PNC seriam mais significativos, pois se estaria gerando novos empregos e melhor remunerados, possibilitaria o aumento da área de cultivo de erva-mate com o que mais produtores poderiam se envolver na atividade, ocorreria qualificação do processo produtivo, oportunizaria maior arrecadação tributária, com isso, melhorando o retorno de recursos para

${ }^{18}$ No dossiê, do qual faz parte este artigo está publicado resultados de pesquisas neste setor. 
os poderes públicos disponibilizarem no investimento em novos serviços públicos, dentre outros aspectos positivos.

Esse reposicionamento do setor industrial ervateiro do PNC é fundamental, dentre outras razões, para superarmos uma característica histórica da região: a tradição extrativista da economia. Isso, pois, o extrativismo vegetal, como atividade econômica é a que menos riqueza gera, por agregar pouco valor à produção. Isso ocorreu com a fase extrativista das madeiras nobres do início até meados do fim do Século XX. No caso da erva-mate, considerando que nos primórdios de sua exploração, a maior parte saia da região na forma in natura, sendo beneficiada em outros centros urbanos, podemos também falar numa atividade de caráter extrativista. Ao constatar que, atualmente, parte significativa da erva-mate é exportada na forma de produto semibeneficiado, poderíamos afirmar que a atividade não superou totalmente o caráter de economia predominantemente extrativista ${ }^{19}$.

Uma última reflexão: quando fizemos referência às condições que o meio institucional oferece ou deixa de oferecer ao setor ervateiro regional, dividimos a responsabilidade entre empresários do setor e as instituições públicas e privadas do PNC. Ou seja, para contribuir no avanço e inovações no setor ervateiro regional, precisamos regionalmente assumir o caráter de um "território inovador", nos tornando capazes de gerar ou incorporar conhecimentos necessários para atribuir valor de forma eficiente e racional aos nossos recursos e ativos. Outra recomendação de autores referenciados é que a capacidade inovadora regional é que viabiliza a inserção de empresas e territórios no espaço mundial, inserindo-se em elos da cadeia produtiva e de distribuição que permitam maior agregação de valor aos seus produtos e serviços (FERRÃO, 1996; MÉNDEZ, 2002; CARAVACA; GARCÍA, 2009).

E quais as implicações das recomendações dos autores quanto à dimensão coletiva da inovação, no caso do setor ervateiro do PNC? Uma delas, que já está sendo operacionalizada em parte, é o aumento das pesquisas científicas de parte das instituições universitárias localizadas regionalmente, muitas das quais resultarão em inovações no setor ${ }^{20}$. Outra, a necessidade de instituir regionalmente um centro ou instituto de pesquisa e inovação da ervamate, na forma de rede, integrando instituições regionais, tais como a UnC, a Epagri, o Instituto Federal Santa Catarina, escolas técnicas agrícolas e a Embrapa Florestas, esta última situada no vizinho estado do Paraná. Esta segunda recomendação, não deixa de ser uma ousadia, proposta por nós pesquisadores, que nos parece ter muita urgência. Um bom exemplo, que pode inspirar-nos, é o que decorre da experiência da IG Região do Cerrado Mineiro, o caso do Centro de Excelência do Café do Cerrado ${ }^{21}$. Da mesma forma, é importante se pensar uma estrutura institucional responsável pela gestão do centro de pesquisa

\footnotetext{
${ }^{19}$ Até este estágio de investigação não chegamos a apurar o montante representado pela exportação, do total da erva-mate beneficiada na região. No entanto, em conversas informais com empresários, sabe-se que o percentual é significativo, pois, no momento, há uma demanda crescente no mercado externo por erva-mate semibeneficiada.

${ }^{20}$ Vejam-se resultados de pesquisas realizadas recentemente, nos demais artigos desta edição da DRd.

${ }^{21}$ Ver artigo nesta edição da revista DRd sobre o assunto. No artigo referido, se propõe que o processo de estruturação da IG da erva-mate, avance, integrando o recorte territorial de produção de erva-mate próximo ao Planalto Norte Catarinense, no caso da região Centro Sul do Paraná, propondo como referência territorial, a "Região Ervateira do Médio Vale do Rio Iguaçu". É um debate que, mesmo estando presente, ainda é pouco aprofundado, além de não ser aceito por alguns atores envolvidos no processo de discussão da referida IG. No nosso entendimento, como pesquisadores sobre o tema, o aprofundamento do referido debate deve ocorrer com a maior urgência possível, sendo considerado um posicionamento estratégico, considerando as possibilidades de sucesso da futura IG da erva-mate.
} 
e inovação, com a missão de estabelecer linhas de pesquisa, inovação e desenvolvimento de novos produtos à base da erva-mate, além da identificação de novas tecnologias que proporcionem a qualificação e ampliação do setor produtivo rural. Uma estrutura desse tipo teria a possibilidade de promover o intercâmbio permanente de experiências com técnicos e especialistas de diversas regiões produtoras, executando cursos e eventos. Novamente, o exemplo da Fundação de Desenvolvimento do Cerrado Mineiro, pode servir de inspiração.

Espera-se que os dados pesquisados e informações evidenciadas nesta investigação, além das análises e reflexões propositivas oportunizadas, estimulem o debate regionalmente, não só internamente no setor, mas no meio acadêmico, nos órgãos de pesquisa e extensão, no empresariado, na sociedade em geral e de parte dos gestores públicos.

Por fim, reconhecemos as limitações da presente investigação, com o que estamos cientes quanto à necessidade de aprofundar as análises, por meio de novas investigações.

\section{REFERÊNCIAS}

AYDALOT, P. Milieux Innovateurs en Europe. Paris: GREMI, 1986.

BARQUERO, A. V. Los territorios innovadores, espacios estratégicos del desarrollo. In: CURBELO, J. L.; PARRILLI, M. D.; ALBUQUERQUE, F. (coords.). Territorios innovadores y competitivos. Madrid: Marcial Pons Ediciones Jurídicas y Sociales S.A., 2011, p. 75-88.

BARTMANN, S. K. B. Memória Social e Desenvolvimento: uma análise do processo histórico de produção de erva-mate no município de Canoinhas - SC. Santa Cruz do Sul: UNISC, 2009. Dissertação (Mestrado) - Programa de Pós-Graduação em Desenvolvimento Regional. 2009.

BOISIER, S. Decodificando el desarrollo del siglo XXI: subjetividad, complejidad, sinapsis, sinergía, recursividad, liderazgo y anclaje territorial. In: CURBELO, J. L.; PARRILLI, M. D.; ALBUQUERQUE, F. (coords.). Territorios innovadores y competitivos. Madrid: Marcial Pons Ediciones Jurídicas y Sociales, 2011, p. 51-73.

BORGES, R. C. G; GARVIL, M. P.; ROSA, G. A. A. Produção de fitocosméticos e cultivo sustentável da biodiversidade do Brasil. Revista Eletrônica da Reunião Anual de Ciência, v. 3, n. 1, p. 223-233, 2013.

BRAVO, L.; GOYA, L.; LECUMBERRI, E. LC/MS characterization of phenolic constituents of Mate (Ilex paraguariensis St. Hil.) and its antioxidant activity compared to commonly consumed beverages. Food Res Int., v. 40, p. 393-405, 2007.

CAMAGNI, R. (ed.). Innovation networks. Spatial perspectives. London: GREMIBelhaven Press, 1995.

CARAVACA, I. B.; GARCÍA, A. G. El debate sobre los territorios inteligentes: el caso del área metropolitana de Sevilla. Revista Eure, v. 35, n. 105, p. 23-45, ago. 2009. 
CREVOISIER, O. Industrie et région: les milieux innovateurs de l'Arc jurassien. Neuchâtel: EDES, 1993.

DALLABRIDA, V. R. Desenvolvimento Regional: por que algumas regiões se desenvolvem e outras não? Santa Cruz do Sul (RS): Edunisc, 2010.

DALLABRIDA, V. R. Governança territorial: do debate teórico à avaliação da sua prática. Análise Social, v. 50(2º), n. 215, p. 304-328, 2015.

DALLABRIDA, V. R. Território, Governança e Desenvolvimento Territorial: indicativos teórico-metodológicos, tendo a Indicação Geográfica como referência. São Paulo: Editora LiberArs, 2016.

FARINÓS, J. D. Inteligencia Territorial para la planificación y la gobernanza democráticas: los observatorios de los territorios. Proyeccion 11, v. 5, p. 45-69, set. 2011.

FERRÃO, J. Educação, sociedades cognitivas e regiões inteligentes: uma articulação promissora. Inforgeo - Revista da Associação Portuguesa de Geógrafos, n. 11, p. 97-104, 1996.

FLORIDA, R. Oward the Learning Region. Futures, v. 27, n. 5, p. 527-536, 1995.

GIRARDOT, J. J. Evolution of the concept of territorial intelligence within the coordination action of the European network of territorial intelligence. Res-Ricerca e Sviluppo per le Politiche Sociali, n. 1-2, p. 11-29, 2009.

LANZETTI et al. Mate tea reduced acute lung inflammation in mice exposed to cigarette smoke. Nutrition, v. 24, n. 4, p. 375-81, 2008.

LUNDVALL, B. National Systems of Innovation: Towards a Theory of Innovation and Interactive Learning. Londres: Pinter Publishers, 1992.

MAFRA, A. D. Aconteceu nos ervais: a disputa territorial entre Paraná e Santa Catarina pela exploração da erva-mate - Região Sul do Vale do Rio Negro. Canoinhas: Universidade do Contestado, 2008. Dissertação (Mestrado) em Desenvolvimento Regional. 2008.

MAILLAT, D. Globalização, meio inovador e sistemas territoriais de produção. Interações, Campo Grande (MT), v. 3, n. 4, p. 9-16, mar./2002.

MAILLAT, D. Les milieux innovateurs. Sciences Humaines, n. 8, p. 41-57, 1995.

MAILLAT, D.; QUÈVIT, M.; SENN, L. (eds.). Resaux d'Innovation et Milieux

Innovateurs: un Pari pour le Dévelopment Régional. Neuchâtel: GREMI-EDES, 1993.

MARQUES, A. C. As paisagens do mate e a conservação socioambiental: um estudo junto aos agricultores familiares do Planalto Norte Catarinense. Curitiba, 2014. Tese (Doutorado) - Universidade Federal do Paraná - Doutorado em Meio Ambiente e Desenvolvimento. 2014.

MÉNDEZ, R. Innovación y desarrollo territorial: algunos debates teóricos recientes. Revista EURE, v. 28, n. 84, p. 63-83, 2002. 
MORAES, F. P.; COLLA, L. M. Alimentos funcionais e nutracêuticos: definições, legislação e benefícios à saúde. Revista Eletrônica de Farmácia, v. 3, n. 2, p. 109-122, 2006.

MORAIS, E. C. et al. Consuption of Yerba Mate (Ilex paraguariensis) Improves Serum Lipid Parameters in Healthy Dyslipidemic Subjects and Provides na Additional LDL-Cholesterol Reduction in Individuals on Statin Therapy. Journal of Agricultural and Food Chemistry, v.57, n.18, p. 8316-24, 2009.

NELSON, R. R. (Ed.). National Innovation Systems: a Comparative Analysis. Nova Iorque: Oxford University Press, 1993.

SANTOS, D. Teorias de inovação de base territorial. In: COSTA, J. S.; NIJKAMP, P. (coords.). Compêndio de Economia Regional. 1a. ed. Cascais (Portugal): Princípia Editora Ltda, 2009, p. 319-352 (Vol. 1 - Teoria, temáticas e políticas).

SCHUMPETER, J. A. Teoria do desenvolvimento econômico: uma investigação sobre lucros, capital, crédito, juro e o ciclo econômico. São Paulo: Abril Cultural, 1982 (Coleção Os Economistas).

SOUZA, A. M. Dos ervais ao mate: possibilidades de revalorização dos tradicionais processos de produção e de transformação de erva-mate no Planalto Norte Catarinense. Florianópolis, 1998. Dissertação (Mestrado) - Universidade Federal de Santa Catarina Mestrado em Agroecossistemas. 1998.

VIBRANS, A. C. et al. (Eds.). Floresta Ombrófila Mista. Vol.3. Blumenau: Edifurb, 2013. 440p. (Inventario Florístico e Florestal de Santa Catarina). 


\section{ANEXO A - ESTUDO DO SETOR INDUSTRIAL ERVATEIRO DO PLANALTO NORTE CATARINENSE}

Objetivo: Caracterizar a cadeia produtiva da erva-mate dos municípios do Planalto Norte Catarinense. Os dados farão parte de estudos que estão sendo realizados por dois alunos da Universidade do Contestado, orientados pelo Prof. Dr. Valdir Roque Dallabrida. As informações serão utilizadas, exclusivamente, para estudo acadêmico, os quais não serão disponibilizados individualmente, ou seja, não será informado o nome da empresa, nem do empresário.

\section{Localização da empresa:}

( ) Bela Vista do Toldo ( ) Campo Alegre ( ) Canoinhas ( ) Irineópolis ( ) Itaiópolis

( ) Mafra ( ) Major Vieira ( ) Monte Castelo ( ) Papanduva ( ) Rio Negrinho

( ) Porto União ( ) São Bento do Sul ( ) Três Barras

\section{Data de fundação:}

Ano:

3. Origem da matéria-prima utilizada no beneficiamento industrial:

( ) De municípios do Planalto Norte Catarinense - percentual \%:

( ) De outros municípios do Estado de Santa Catarina - \%

( ) De municípios do Paraná, próximos à nossa região \%

( ) De outros Estados brasileiros

( ) De outros países, como a Argentina

$\%$

$\%$

4. Relação de produtos da empresa e época em que se iniciou a comercialização do produto:

a- ( ) erva-mate para chimarrão:

( ) desde o início da empresa

( ) a partir do ano

b- ( ) erva para chás:

( ) desde o início da empresa

( ) a partir do ano

c- Outros produtos

$1-$

2-

3-

4-

$5-$

Ano em que a empresa iniciou a comercialização

5. Você considera que a quantidade de produtos que a empresa comercializa:

( ) É suficiente para manter a competitividade da empresa

( ) Poderia ser maior, pois melhoraria a competitividade da empresa

6. Se considera que a empresa poderia atuar no mercado com mais produtos, qual o motivo que justifica não ter ampliado a quantidade:

( ) Não tem mercado regional

( ) Mesmo tendo mercado fora da região ou no exterior, as atividades atuais da empresa são suficientes para manter-se no mercado

( ) Outros motivos, quais: 
7. Sobre a atividade industrial e comercial da empresa e volume de produção mensal (média):

a- ( ) A industrialização e comercialização de produtos no mercado consumidos regional e nacional representa um percentual de:

( ) 100\% ( ) entre 70 e $99 \%$ ( ) entre 50 e $69 \%$ ( ) menos de $50 \%$

b- A industrialização e comercialização de produtos no mercado internacional representa um percentual de:

( ) 100\% ( ) entre 70 e $99 \%$ ( ) entre 50 e $69 \%$ ( ) menos de $50 \%$

c- Do total da atividade comercial e industrial da empresa, a exportação de erva-mate semibeneficiada (ex. cancheada), representa um percentual de:

( ) $100 \%$ ( ) entre 70 e $99 \%$ ( ) entre 50 e $69 \%$ ( ) menos de $50 \%$

8. Sobre inovação empresarial:

a- A empresa tem inovado historicamente, e em que?

b- Se você considera que a empresa tem inovado pouco ao longo de sua história, quais as razões que você aponta como justificativas?

9 Relacione os fatores que você considera favoráveis ao sucesso do setor industrial da ervamate do Planalto Norte Catarinense:

10 Quais as principais dificuldades que você aponta para o setor industrial ervateiro da região?

\footnotetext{
Algo mais que gostaria de registrar?
}

Agradecemos imensamente sua disponibilidade em responder nossas questões. Com certeza contribuirão para refletirmos sobre o fortalecimento do setor ervateiro de nossa região.

Os autores da Pesquisa

Artigo recebido em: 15/07/2016

Artigo aprovado em: 20/07/2016 